is included, with approved symbols and the laboratories in which they are maintained. Reprints can be obtained from the Director, Laboratory Animals Bureau, Medical Research Council Laboratories, Holly Hill, Hampstead, London, N.W.1 ; or from Dr. G. D. Snell, Roscoe B. Jackson Memorial Laboratory, Bar Harbor, Maine.

\section{The Night Sky in July}

FULx moon occurs on July 7d. 12h. 33m., U.T., and new moon on July $21 \mathrm{~d}$. 23h. 30m. The following conjunctions with the moon take place: July 2d. 16h., Mars $4^{\circ}$ N.; July 16d. 04h., Jupiter $7^{\circ}$ S.; July 24d. 04h., Mercury $2^{\circ} \mathrm{S}$. ; July 28d. 04h., Saturn $7^{\circ}$ N.; July 30d. 19h., Mars $4^{\circ}$ N. Mercury, an evening star, sets at $21 \mathrm{~h} .40 \mathrm{~m} ., 21 \mathrm{~h} .10 \mathrm{~m}$. and $20 \mathrm{~h}$. $0 \mathrm{~m}$. at the beginning, middle and end of the month, respectively, and is visible in the western sky after sunset, stellar magnitude 1.6. Venus sets too soon after the sun for favourable observation. Mars is an evening star, setting at $0 \mathrm{~h} .10 \mathrm{~m} ., 23 \mathrm{~h} .25 \mathrm{~m}$. and $22 \mathrm{~h}$. $35 \mathrm{~m}$. on July 1,15 and 31 , respectively, its stellar magnitude varying between -0.5 and 0 . Towards the end of the month it is a little south of $\alpha$ Libræ. Jupiter is visible in the early morning hours, its times of rising being $0 \mathrm{~h} .50 \mathrm{~m} ., 23 \mathrm{~h} .55 \mathrm{~m}$. and $23 \mathrm{~h} .05 \mathrm{~m}$. at the beginning, middle and end of the month, respectively. Saturn is visible until late in the evening, its times of setting being $23 \mathrm{~h}$. $50 \mathrm{~m}$., $22 \mathrm{~h} .55 \mathrm{~m}$. and $21 \mathrm{~h} .55 \mathrm{~m}$. on July 1,15 and 31 , respectively. The planet is close to $\gamma$ Virginis throughout the month and its stellar magnitude is $1 \cdot 1$. Occultations of stars brighter than magnitude 6 are as follows, observations being assumed at Greenwich : July 10d. 0h. 01·2m., 44 Capr. $(R)$; and July 10d. 0h. $24 \cdot 1 \mathrm{~lm}$., 45 Capr. $(R) . \quad R$ refers to reappearance. The earth reaches aphelion on July 3.

\section{Announcements}

Dr. Frans Verdoorn, editor of Chronica Botanica and chairman of the International Phytohistorical Commission, Waltham, Mass., has been elected a corresponding member of the Royal Netherlands Academy of Sciences of Amsterdam.

THE title of reader in chemical pathology (cancer research) in the University of Birmingham has been conferred on Dr. D. L. Woodhouse, lecturer and senior research fellow. The following appointments have recently been made in the University : W. $O$. Storer, to be lecturer in education (mathematics), in succession to E. C. Cull, who is retiring; R. F. King, to be Imperial Chemical Industries, Ltd., fellow in geology.

The Chemical Society is offering a Corday-Morgan Award for 1951, consisting of a silver medal and monetary prize (150 guineas), which will be made to the British chemist who, in the judgment of the Council, published during the year 1951 the most meritorious contribution to experimental chemistry, and who, at the date of publication, had not attained the age of thirty-six years. Applications or recommendations in respect of the Award must be received not later than December 31, 1952. Further information can be obtained from the General Secretary of the Society at Burlington House, London, W.1.

An Arnold Gerstenberg Studentship for 1953 ( $£ 170$ a year for two years) is being offered to students in the University of Cambridge with honours in the Natural Sciences Tripos, who went into residence not earlier than the Easter Term of 1947, and who wish to pursue a course of philosophical study. The Studentship will be awarded for an essay which must be submitted before June 1, 1953. Full details can be obtained from Mr. R. B. Braithwaite, King's College, Cambridge.

THe eighth meeting of the International Commission on Glass will be held in London and Sheffield during June 30-July 5, under the presidency of Prof. W. E. S. Turner. The Commission, which includes the leading glass technologists from all Western European countries, Japan and the United States, exists to promote co-operative effort between members, to act as a clearing house for international, technical and scientific work and to transmit to the constituent societies scientific problems of international importance. Further particulars can be obtained from the Glass Manufacturers' Federation, 17 Manchester Street, London, W.1.

A Machinery and Implement Exhibition will be held at the Sports Turf Research Institute (formerly Board of Greenkeeping Research), St. Ives Research Station, Bingley, Yorkshire, during July 15-16. The laboratories at the Research Station, the experiment grounds and the Permanent Implement Exhibition will be open for inspection.

THE 'Present Question' Conference this year will be on "Conflicts of Loyalties" and will be held at Lady Margaret Hall, Oxford, during August 2-9. A number of lectures will be given in the mornings by leading experts, each one of whom will discuss a particular facet of conflicting loyalties in contemporary life. In the late afternoons and evenings study groups and discussions will be held. The fee for the Conference is 2 guineas (students, 1 guinea). Further details can be obtained from the Secretariat, Present Question Conference, 37 Middleway, London, N.W.11.

A WorLd Congress of Medical Practitioners for the Study of the Actual Conditions of Life will be held during October 16-18 in Montecatini, a well-known spa between Pistoia and Pisa. The Congress, which will be on the lines of the International Medical Congress held in Rome during November 10-11, 1951, will be under the presidency of Prof. Pietro Verga, director of the Institute of Anatomy and Pathological Histology and of the Institute for Cancer Research, University of Naples. Three themes will be discussed: conditions of life and the health of populations ; the repercussions of the Second World War on physical and mental health; and the duty of medical practitioners with regard to these problems. Further information can be obtained from the Secretariat of the Congress, Corso Trieste 65, Rome.

THE Departments of Extra-Mural Studies and of Electrical Engineering of the University of Birmingham are arranging a summer school on the fundamental characteristics of electronic apparatus, to be held in the University, Edgbaston, during July 14-19. The course is intended for engineers and others of university degree or similar standing in electrical technology who have some general knowledge of electronics. The following topics will be discussed: limitations of thermionic valves, thyratrons and ignitrons, circuits, semi-conductors, photo-cells and magnetic amplifiers; each topic will be introduced by $a$ theoretical lecture, and will be followad by consideration of particular applications. The fee for the course is $£ 2$. Further details can be obtained from the Director of Extra-Mural Studies, University, Edmund Street, Birmingham 3. 